\title{
Analysis of Organizational Culture in Affiliated and Independent Imam Hatip Middle Schools*
}

\author{
İbrahim Erdem ${ }^{1}$
}

\author{
Yusuf Alpaydın ${ }^{1}$ \\ Marmara University
}

\begin{abstract}
Different opinions exist about the effects of combining secondary schools with high schools in the same building/campus under a single administration of teachers and students. Imam Hatip middle schools in Turkey can be found both on the site of high school buildings and as individual buildings. The purpose of this research is to examine how the organizational culture in these middle schools, whether independent or affiliated with a high school, differs. In this context, a mixed method consisting of a combination of quantitative and qualitative research methods has been used. The universe of the quantitative research is composed of the teachers working in Imam Hatip Middle Schools affiliated with the Tuzla, Pendik, Kadıköy, Ataşehir, and Üsküdar Districts' Directorate of National Education. The Organizational Culture Scale was applied to a total of 298 teachers, who had been identified using appropriate sampling from this universe. In the qualitative part of the study, semi-structured interviews were held with 10 teachers and five school administrators working in independent or affiliated Imam Hatip Middle Schools. No significant difference was found for the total scores from the school culture scale with scores for any subscale according to the variables of gender, branch, school type, or seniority as applied to the teachers in the study. According to the variable of age, however, a significant difference was found in the means of these groups for the sub-dimension of information flow. During the interviews, the teachers talked about a culture common in Imam Hatip schools called Imam Hatip culture. Many teachers and administrators believe that İmam Hatip Middle Schools should be unaffiliated with high schools. Some teachers and administrators recommend that these middle schools should be taught on the same site as high schools. However, all teachers indicated the schools have cultural differences. The interviewed managers and teachers emphasized the existence of problems in crowded and affiliated schools, especially in inter-teacher communications. Teachers were said to not communicate with other groups and to be in a status race with each other. Combining middle and high school training leads to spatial distress in many schools. Teachers often think that high school students, by exhibiting adverse behavior, are a bad example to middle school students. However, high school students were also emphasized to be able to influence adolescents through exemplary behavior. Differences in regulations have been stated to lead to implementation difficulties. Legislative differences cause an overload of administrative work. Separated jobs force field checks and make communication difficult. Regulations that have been passed on disciplinary procedures, the ins and outs of specific days and weeks, course choices, and course completion have been stated as making school administration difficult. Finally, based on teachers' views, independent management has been proposed for Imam Hatip Middle Schools in order to have an effective school culture.
\end{abstract}

\section{Keywords}

Education • Culture • School Culture • Imam Hatip Middle School • Imam Hatip High School

\footnotetext{
* This is an extended abstract of the paper entitled "İmam Hatip Lisesi Bünyesindeki İmam Hatip Ortaokullarıyla Müstakil İmam Hatip Ortaokullarındaki Örgüt Kültürünün İncelenmesi” published in Talim: Journal of Education in Muslim Societies and Communities.

Manuscript Received: October 25, 2017 / Accepted: December 12, 2017 / OnlineFirst: December 25, 2017.

1 Correspondence to: İbrahim Erdem, Muzafferda Güzide Pulur İmam Hatip Ortaokulu, İstanbul Turkey. Email: ibrahimerdem08@gmail.com

2 Marmara University, Atatürk Faculty of Education, Department of Educational Sciences, Kadıköy, İstanbul Turkey. Email: yusuf.alpaydin@marmara.edu.tr

To cite this article: Erdem, İ., \& Alpaydın, Y. (2017). Analysis of organizational culture in affiliated and independent Imam Hatip Middle Schools. Talim: Journal of Education in Muslim Societies and Communities. 1, 187-218. http://dx.doi.org/10.12738/talim.2017.2.0014
} 
In school culture studies, as in institutional culture studies, the values shared by members; belief systems; manner of solving members' problems; school's history and traditions; and myths, heroes, and symbols have been expressed as the determinants of school culture (Alemdar \& Köker, 2013, p. 235). Being an open social system, schools influence cultural structure through their culture and the functions they undertake in transferring culture to new generations, as well as being affected by the cultural structure. School culture expresses the values, beliefs, and symbols that influence students', teachers', school administrators', and all employees' behaviors (Wren, 1999). According to Owens (1987), a school's non-written behavioral patterns, traditions, beliefs, and ceremonies are learned as symbolic elements of school culture and transferred from one generation to another in school organizations.

The most radical change in the level structure of the Turkish education system was made in 2012. This change is also closely related to the Imam Hatip High Schools. Through the Law on Structuring Change in Certain Laws and the Law of Primary Learning and Education No. 6287 (passed on April 11, 2012), eight years of continuous compulsory education were increased to 12 years of graduated education; the 12-year period has been divided into three stages. The first stage is accepted as four years of primary school, the second as four years of middle school, and the third as four years of high school. Another amendment was also passed in the form of the first paragraph of Article 25 from the Basic Education Law No. 1739: "Primary education institutions consist of a four-year process, and the compulsory primary schools and four-year process consist of middle schools and Imam Hatip Middle Schools that allow for the choice between compulsory and alternate programs. Through this same law, Article 24 of Law No. 1739 allows for the possibility of opening middle schools/Imam Hatip Middle Schools on the site of a high school by being amended in the form of "The establishment of primary education institutions in the form of independent schools being primary and secondary schools is essential. However, middle schools can also be established together with primary schools or high schools depending on the conditions and circumstances."

Different opinions are found on the topic of the effects on teachers and students of gathering high schools with middle schools under one management within the same building/campus. Imam Hatip Middle Schools can be found in Turkey as buildings that are both unaffiliated or on the site of a high school. The purpose of this research is to investigate how the organizational culture of independent and affiliated Imam Hatip Middle Schools differs.

This study uses mixed methods consisting of a combination of quantitative and qualitative research methods. The universe of the study is composed of teachers working in official Imam Hatip Middle Schools affiliated with the National Education 
Directorate of the Districts of Tuzla, Pendik, Kadiköy, Ataşehir, and Üsküdar. The Organizational Culture Scale (Öztürk, 2015) was applied to a total of 298 teachers determined by way of appropriate sampling from within this universe. Qualitative survey questions using a personal information form and the Organizational Culture Scale were used for the purpose of collecting data from the teachers in the sample group. The data obtained from the scales were resolved by coding in a computer environment with the assistance of the SPSS package program. In the binary comparisons, frequency and percentage distributions were taken related to data using the first part of the scale and the means and standard deviations were used to reveal the differences between attitudes. In comparing the two groups, the $t$-test was used for normal distributions and one-way analysis of variance (ANOVA) was used when comparing groups of more than two variables. Semi-structured interviews were performed in the qualitative section of the study with 10 teachers and five school administrators working at affiliated or independent Imam Hatip Middle Schools. The semi-structured interview form aims to identify specific differences after applying the Organizational Culture Scale. When forming the qualitative research questions, expert opinions were sought. In addition, research performed on this topic has been investigated. The descriptive analysis method was used in the qualitative data analysis. Analyses were performed by creating themes from the given answers.

No significant difference was found for the scores from the school culture scale applied to teachers in the study for any sub-dimension with the total scale according to the variables of gender, branch, type of school where they work, or seniority. While a significant difference according to the variable of age was found in the sub-dimension of information flow among the groups' mean scores from the Organizational Culture Scale applied to teachers forming the sample group, no significant difference was found in the other dimensions with the total scale. This difference of teachers in the 41-and-older age group's school culture perceptions with the 36-40 year-old teachers was seen to be more positive in the sub-dimension of information flow. No significant difference exists among the other groups.

During the interviews, the teachers talked about a common culture that is in the Imam Hatip schools, which they describe as Imam Hatip culture. They stated that, unlike other schools, a different, curriculum-driven culture is found in Imam Hatip Middle Schools, and this culture is present in both the Imam Hatip Middle and High Schools. Many teachers and administrators think the Imam Hatip Middle Schools need to be unaffiliated. The research participants think independent schools have a more advantageous position in terms of being able to create their own cultural heritage. In particular, the difference of vision in schools was identified as being able to harm school culture in Imam Hatip Middle Schools found on high-school sites for reasons such as high-school students harassing the middle-school students and 
being bad examples. Teachers expressed that having schools together at the middle and high-school level with different goals and visions makes reaching these goals hard for them. Also mentioned were that students who study at Imam Hatip Middle Schools located on a high-school site use the same building as the high school, carry the same emblems on their school uniforms, and don't feel that they belong at their own school. High-school students were mentioned as also being able to affect middleschool students through their negative behaviors. The teachers consider high-school students to be a bad example to middle-school students through the mostly negative behaviors that they exhibit. Some of the teachers and administrators suggested seeing middle-school students educated together with high-school students. Being educated together has been identified as maybe being useful for achieving common values. If high-school students have a high level of success, middle-school students' level of academic success can also increase. The administrators and teachers who were interviewed stressed the problems they had experienced in communications among teachers, especially in crowded and affiliated schools. Teachers were identified as being unable to communicate with other groups and to be in a race of levels with each other. Teachers were also identified as being able to experience problems in course load and scheduling in schools found on high school sites, while also paying attention to the fact that high-school students in needs schools also are taking classes in the middle schools. Seeing competition among teachers was noted as possible. Classifications among teachers such as "high school teacher" and "middle-school teacher" were also identified. The implementation of different regulations was also stated as opening the way to difficulties. Having high schools with middle schools subjected to different regulations was also identified as problematic from the perspective of both administrators and teachers. Managing a school through different regulations in the same building can cause confusion for teachers. Administrators in Imam Hatip Middle Schools located on high-school sites identified needing to have mastery in both Primary Educational Institution Administration and Middle School Educational Institution Administration. Attention is drawn to the difficulties of school administrators with respect to the two separate regulations. Legislative differences cause an overload of administrative work. Sharing the workload forces field checks and makes communication difficult. Differences in the way of legislating disciplinary actions, the processes of specific days and weeks, course selection, and course completions have been identified as making school administration difficult. As a result and based on the teacher interviews, Imam Hatip Middle Schools are suggested for independent administration in order for them to have an effective school culture. 